\title{
Antibacterial Activity of Bacteria Isolated from Fermenting Cocoa Water against Some Pathogenic Bacteria
}

\author{
Kehinde Tope Adegbehingbe ${ }^{1 *}$, Soji Fakoya ${ }^{2}$, Marcus Oluyemi Bello ${ }^{1}$, \\ Charles Ayodeji Osunla ${ }^{1}$ and Samson Olumide Akeredolu ${ }^{1}$ \\ ${ }^{1}$ Department of Microbiology, Adekunle Ajasin University, Akungba-Akoko, Nigeria \\ ${ }^{2}$ Department of Biological Sciences, Ondo State University of Science and Technology, \\ Okitipupa, Ondo State, Nigeria \\ *Corresponding author
}

\section{A B S T R A C T}

The antimicrobial activity of bacteria isolated from fermenting cocoa water at a local farm at Supare-Akoko Ondo State, Nigeria against selected enteropathogenic bacteria was investigated. The fermentation was monitored for three days while the antimicrobial

\section{Keywords}

Fermentation,

Cocoa,

Microorganisms, antibacterial

\section{Article Info}

Accepted:

04 June 2019

Available Online:

10 July 2019 activity of the predominant isolates was evaluated using agar well diffusion method. The selected organisms were Klebsiella, pneumonia, Salmonella paratyphii, Staphylococcus aureus, Proteus mirabillis, Escherichia coli and Enterococcus faecalis. Bacteria that were isolated from the fermenting cocoa juice include Bacillus licheniformis, B. licheniformis, B. subtilis, B. cereus, Lactobacillus plantarum, L. brevis and Lactococcus lactis. The total viable count and lactic acid bacteria count of the fermenting juice increased from $7.94 \times 10^{3}$ $\mathrm{cfu} / \mathrm{ml}$ and $3.98 \times 10^{2} \mathrm{cfu} / \mathrm{ml}$ to $1.25 \times 10^{6} \mathrm{cfu} / \mathrm{ml}$ and $3.16 \times 10^{5} \mathrm{cfu} / \mathrm{ml}$ respectively. The $\mathrm{pH}$ of the juice decreased from 5.90 to 4.30 while the temperature increased from $35^{\circ} \mathrm{C}$ to $41^{\circ} \mathrm{C}$. The cell free supernatants of the dominant isolates, L. plantarum and L. brevis, inhibited all the pathogenic microbes. The highest and the lowest zones of inhibition were observed in $S$. aureus and E. faecalis cultures respectively. The antibacterial activity of these bacteria could be due to their ability to produce varieties of antimicrobial substances such as organic acids, hydrogen peroxide, carbon dioxide, and bacteriocins. Consumption of fermented cocoa juice could be an economical alternative approach to the use of antibiotics in treating infections caused by these pathogens.

\section{Introduction}

Antimicrobial agents are general nomenclature for all drugs or chemical substances that act on microorganisms either to kill or suppress their growth. Antimicrobial agents with selective toxicity are especially useful as chemotherapeutic agents in treating infectious diseases (Prescott et al., 2008). They can exert their effect on microorganisms in any of the following ways; protein synthesis inhibition, inhibition of cell wall synthesis, inhibition of nucleic acid synthesis (Kimball and Jefferson, 2006). The preservative activities of these microorganisms are due to their ability to produce a variety of antimicrobial substances as a natural competitive means to overcome other microorganisms sharing the same niche (Olivera et al., 2000). Cocoa belongs to the family Malvaceae esterculiacea. It is a 
neotropical species native to the humid tropical plains of Central and South America (Whitkus et al., 1998). The raw cocoa beans possess astringent and bitter flavours which have to be processed after harvest before they can be converted to good taste and flavoursome fruit juice (cocoa water). The quality of the final cocoa beans is determined by curing which involves fermentation followed by drying of the cocoa beans (Biehl et al., 1996).

Evidence had it that cocoa pulp is composed of $82 \%-87 \%$ of water, $10 \%-15 \%$ of sugar (Ardhana et al., 2003). The cocoa water is usually milky in colour which can be consumed fresh or after fermentation. The water (cocoa juice) becomes an alcoholic drink due to the fermentative action of the constituent microorganisms. Of the sugar present in fermenting cocoa water, about $60 \%$ is sucrose and $39 \%$ are mixture of glucose and fructose (Lopez, 2007). During its fermentation, the anaerobic yeasts present in the fermenting cocoa water ferment the sugar to ethanol and also decrease the ph of the cocoa water. During fermentation, the growth of pathogens, as well as other spoilage organisms is frequently inhibited through antimicrobial components produced by fermenting microorganisms (Park et al., 2005). These antimicrobial components produced by lactic acid bacteria include organic acids, hydrogen peroxide, carbon dioxide, acetaldehyde, diacetyl, ethanol and bacteriocins (González et al., 2007). In cocoa fermentation, lactic acid bacteria occur in large number and confer qualities like extended shelf life, aroma and make the product safe for consumption. In fact, the cultures of lactic acid bacteria have the ability to produce antimicrobial metabolites to combat contamination caused by microbial pathogens, especially on cocoa commodities (Motarjemi, 2002).
Cocoa has become an important ethnomedicinal plant since due to its unique chemical composition which is more than 500 different compounds. Among the reported contributions of cocoa to human health, are the antioxidant (Jalil and Ismail, 2008), antiinflammatory (Cragg et al., 2005), anticarcinogenic (Maskarinec, 2009) and antimicrobial activities (Fapohunda and Afolayan, 2012).The intake of fermenting cocoa water reduces anxiety while also promoting alertness. A cup of cocoa juice can provide the same energy as a cup of coffee. They are considered to be nature's antidepressant. Cocoa contains dopamine, phenylethylamine (PEA) and serotonin, all of which are used to promote positive mental health and moods. It was shown that the polyphenols in cocoa beans might improve sensitivity to insulin. Scientists are currently studying the connection between obesity and condition known as insulin resistance syndrome (Cragg et al., 2005).

The aim of this project is to study the effect of the cell free culture isolates of bacteria involved in fermentation of cocoa beans water (cocoa juice) as an antimicrobial feature to inhibit growth of selected pathogenic bacteria such as Klebsiella pneumoniae, Salmonella paratyphii, Staphylococcus aureus, Proteus mirabillis, Escherichia coli and Enterococcus faecalis.

\section{Materials and Methods}

\section{Collection of samples and screening of test organisms}

Fermented cocoa water samples were aseptically collected from a local farm in Supare-Akoko Ondo state into sterile bottles and immediately transported to the Microbiology laboratory of Adekunle Ajasin University, Akungba-Akoko, Nigeria. The cocoa water was fermented for 3 days in a 
sterile bucket and was hermetically covered. The morphological and biochemical test were carried out to ascertain proper identification of the isolates. They were thereafter sub cultured into nutrient agar slants and stored at $4^{\circ} \mathrm{C}$ in the laboratory refrigerator.

Klebsiella pneumoniae, Salmonella paratyphii, Staphylococcus aureus, Proteus mirabillis, Escherichia coli and Enterococcus faecalis were collected from the Microbiology laboratory of Ondo State Specialist Hospital (OSPH), Ikare, Ondo State, Nigeria.

Isolation and enumeration of microorganisms from the cocoa water sample

Ten $\mathrm{ml}$ of the sample was added to $90 \mathrm{ml}$ of normal saline to make the initial dilution. This suspension was homogenized by gentle manual agitation and serially diluted from $10^{-1}$ to $10^{-10}$. Isolation of the bacteria was done using pour plate method on de Mann Rogosa Sharpe (MRS) and Nutrient media. Bacterial cultures were incubated at $35^{\circ} \mathrm{C}$ for $1-2$ days. MRS plates were incubated under anaerobic conditions simulated using a $\mathrm{H}_{2} / \mathrm{CO}_{2}$ generating kit (Oxoid) according to the manufacturer's instructions. Enumeration and isolation were done on daily basis during the fermentation period. Counts were expressed in colony-forming unit per $\mathrm{ml}$ of sample. The isolates were subcultured repeatedly until pure isolates were observed. The slants of the respective pure isolates were prepared and kept in the refrigerator at $4{ }^{\circ} \mathrm{C}$ for subsequent tests (Alexopoulous and Mims, 1988).

\section{Identification of the microorganisms from the samples}

Morphology of the colonies such as shape, colour, size, edge, elevation and surface texture were observed on the plates after 1824 hours of incubation after subsequent streaking on solidified plates. Gram staining and biochemical characteristics of the isolates carried out according to Bergey's Manual of Determinative Bacteriology (Holt et al., 1999).

\section{Determination of total titration acidity (TTA)}

The TTA was determined by titrating $0.2 \mathrm{M}$ of $\mathrm{NaOH}$ against a known amount of the fermenting cocoa water for each day, $25 \mathrm{ml}$ of sodium hydroxide was pipetted into a conical flask; a drop of phenolphthalein indicator was added to give a deep pink colouration. The fermented cocoa water was placed in $50 \mathrm{ml}$ capacity of burette and titrated against the base in conical flask until it brings a light pink colour showing that end point is reached (TTA $=$ Volume of $\mathrm{NaOH}$ used $(\mathrm{ml}) \times 0.009 \times 100 /$ volume of sample used) according to Owuamanam et al., (2011).

\section{pH and Temperature measurement}

The $\mathrm{pH}$ and temperature of the fermenting cocoa water were determined daily using the $\mathrm{pH}$ meter and thermometer, respectively. The $\mathrm{pH}$ was measured by dipping the electrode connected to the meter into a buffer solution to standardize the meter, the electrode was then inserted into the sample and the reading was taken for each day. The temperature was determined by dipping the thermometer into the sample from fermenting cocoa water and the reading was taken by the movement of the mercury in the thermometer (Prescott et al., 2008).

\section{Screening and selection of Lactobacilli with antimicrobial activity}

Screening and selection of lactobacilli colonies of Lactobacillus plantarum and Lactobacillus brevis with antimicrobial activity was done using enteropathogenic 
organisms. The detection was done using the MRS broth. The broth culture was centrifuged at $14,000 \mathrm{rpm}$ for 15 minutes, the supernatants were filtered through a membrane filter of 0.2 $\mu \mathrm{m}$ pores and the resulting cell free supernatant was tested against the selected entero-pathogenic bacteria using agar diffusion assay as described by Onwuakor $e t$ al., (2014).

Screening of cell-free supernatant and cellfree filtrate for antibacterial activities

Agar well diffusion method was used. Three wells of $5.00 \mathrm{~mm}$ in diameter each were made on solidified Mueller-Hinton agar plate seeded with the test bacteria using a sterile cork borer. Equal volume of cell free supernatant the broth cultures was introduced into the wells made on the agar, sterile distilled water and standard antibiotics (ciprofloxacin 20mg/ml) were used as the negative and positive control, respectively. Experiment was carried out in triplicates, zones of inhibition after 24 hours were calculated. Zones of inhibition that are less than 15, between 16 and 22 and between 23 and above were recorded as low susceptibility, moderate susceptibility and high susceptibility, respectively (Adegbehingbe and Bello, 2014).

\section{Results and Discussion}

Two genera of bacteria were identified from the fermenting cocoa water sample during the three-day fermentation period. The genera are Lactoacillus species which comprised Lactobacillus brevis, L. lactis and $L$. plantarum and the Bacillus species which were $B$. cereus, $B$. licheniformis and $B$. subtilis. The predominant microorganisms from the fermenting sample were Lactobacillus brevis and L. plantarum which appeared throughout the fermentation period. Bacillus subtilis and B. licheniformis appeared at the first and the days of fermentation while
B. cereus was isolated only on the second day of fermentation (Table 1).

The microbial counts of the fermenting cocoa water increased during the course of fermentation. The total viable counts increased from $7.94 \times 10^{2} \mathrm{cfu} / \mathrm{ml}$ to $1.25 \times 10^{4} \mathrm{cfu} / \mathrm{ml}$ while the lactic acid bacteria counts increased from $3.98 \times 10^{2} \mathrm{cfu} / \mathrm{ml}$ to $3.16 \times 10^{3} \mathrm{cfu} / \mathrm{ml}$ (Figure 1 ).

Figure 2 shows the $\mathrm{pH}$, TTA and the temperature of the fermenting cocoa juice. The $\mathrm{pH}$ decreased from 5.90 to 4.10 while the total titratable acidity increased from $3.62 \%$ to $4.39 \%$. The temperature of the fermenting cocoa juice increased from $35^{\circ} \mathrm{C}$ to $41^{\circ} \mathrm{C}$ at the third day of fermentation.

Cell free filtrates and supernatants of L. brevis and $L$. plantarum were inhibitory against all the test isolates; Klebsiella pneumoniae, Salmonella paratyphii, Staphylococcus aureus, Proteus mirabillis, Escherichia coli and Enterococcus feacalis. The results revealed variable zones of inhibition with $L$. plantarum having the stronger antibacterial property than L. brevis. The most susceptible among the pathogens was $S$. aureus with zones of inhibition $12.20 \mathrm{~mm}$ and 9.00 against $L$. plantarum and $L$. brevis respectively. Eschericia coli and P. mirabilis had the same zones of inhibition against each of the isolates with values of $8.40 \mathrm{~mm}$ and $8.00 \mathrm{~mm}$ against L. plantarum and L. brevis respectively while the least susceptible among them was E. feacalis having $6.50 \mathrm{~mm}$ and $5.70 \mathrm{~mm}$ respectively (Table 2).

Two genera of bacteria were identified from the fermenting cocoa water sample during the three-day fermentation period. The genera are Lactobacillus species which comprised Lactobacillus brevis, $L$. lactis and $L$. plantarum and the Bacillus species which were $B$. cereus, $B$. licheniformis and $B$. subtilis. 
Fig.1 Bacterial counts of the fermenting cocoa juice

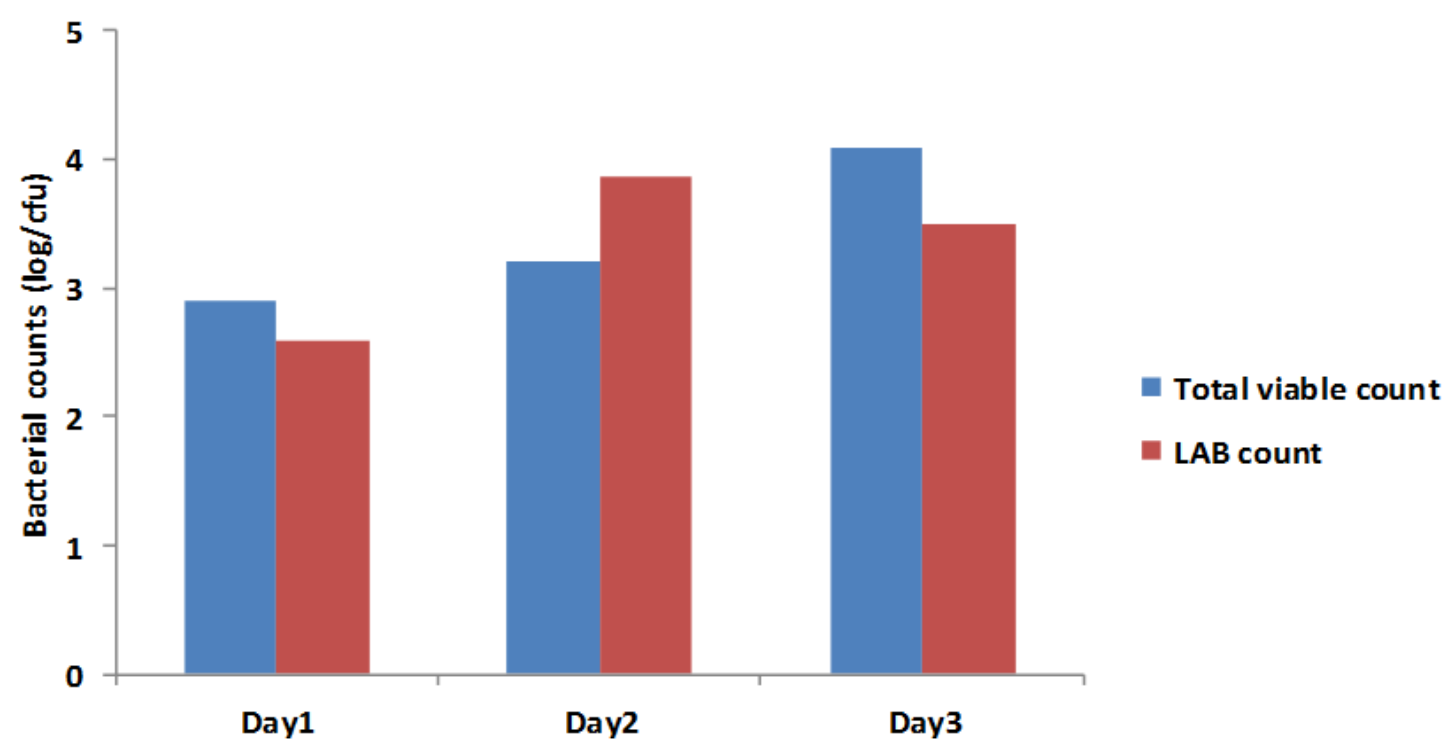

Fig.2 Physico-chemical properties of fermenting cocoa water during fermentation

$\mathrm{pH}$

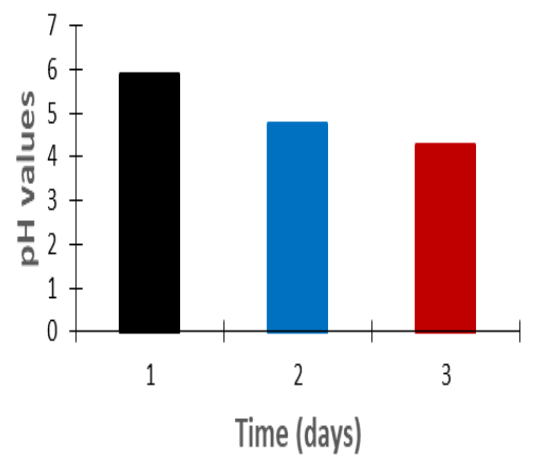

TTA

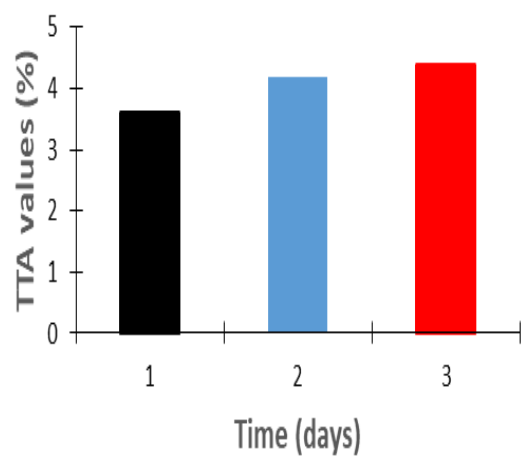

Temperature

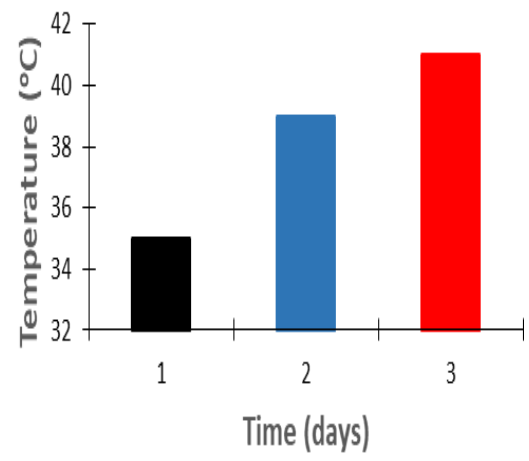

TTA $=$ total titratable acidity.

Table.1 Occurrence of the microorganisms from the fermenting cocoa water

\begin{tabular}{|l|l|l|l|}
\hline Microorganisms & \multicolumn{3}{|l|}{ Days of fermentation } \\
\hline & $\mathbf{1}$ & $\mathbf{2}$ & $\mathbf{3}$ \\
\hline Lactobacillus plantarum & + & + & + \\
\hline Lactobacillus lactis & - & + & + \\
\hline Lactobacillus brevis & + & + & + \\
\hline Bacillus subtilis & + & + & - \\
\hline Bacillus licheniformis & + & + & - \\
\hline Bacillus cereus & - & + & - \\
\hline
\end{tabular}

$+=$ present

- = absent 
Table.2 Antibacterial activity of lactic acid bacteria from fermenting cocoa water against selected pathogenic bacteria

\begin{tabular}{|l|l|l|l|l|l|l|}
\hline \multicolumn{7}{|c|}{ (Inhibition zones in millimeter) } \\
\hline Isolates & E. coli & S. aureus & $\begin{array}{l}\text { Klebsiella } \\
\text { pneumoniae }\end{array}$ & $\begin{array}{l}\text { Proteus } \\
\text { mirabillis }\end{array}$ & $\begin{array}{l}\text { Salmonella } \\
\text { paratyphi }\end{array}$ & $\begin{array}{l}\text { Enterococcus } \\
\text { feacalis }\end{array}$ \\
\hline L. plantarum & 8.40 & 12.20 & 7.20 & 8.40 & 8.20 & 6.50 \\
\hline L. brevis & 8.00 & 9.00 & 6.00 & 8.00 & 7.40 & 5.70 \\
\hline
\end{tabular}

The predominant microorganisms from the fermenting sample were Lactobacillus brevis and L. plantarum which appeared throughout the fermentation period. Bacillus subtilis and $B$. licheniformis appeared at the first and the days of fermentation while $B$. cereus was isolated only on the second day of fermentation (Table 1). De Vuyst et al., (2010) isolated L. plantarum and L. brevis during the fermentation of cocoa. Galvez et al., (2007) reported the presence of Bacillus cereus, Bacillus licheniformis and Bacillus subtilis during the fermentation of cocoa juice. The disappearance of Bacillus species after the second day of fermentation was probably due to high concentrations of antibacterial substances such as bacteriocins produced by the lactic acid bacteria.

Figure 1 shows the pH, TTA and the temperature of the fermenting cocoa juice. The $\mathrm{pH}$ decreased from 5.90 to 4.10 while the total titratable acidity increased from $3.62 \%$ to $4.39 \%$.It is well known that lactic acid bacteria are acid tolerant (Atter et al., 2014). The temperature of the fermenting cocoa juice increased from $35^{\circ} \mathrm{C}$ to $41^{\circ} \mathrm{C}$ at the third day of fermentation. The increase in temperature might be due to the metabolic activities of the fermenting microorganisms leading to heat production. This collaborated with the findings of Olivera et al., (2000) and Lima et al., (2011).

The supernatants of $L$. brevis and $L$. plantarum, which were the predominant isolates, were inhibitory against all the test isolates; Klebsiella pneumoniae, Salmonella paratyphii, Staphylococcus aureus, Proteus mirabillis, Escherichia coli and Enterococcus feacalis. The results revealed variable zones of inhibition with L. plantarum having the stronger antibacterial property than L. brevis.

The most susceptible among the pathogens was $S$. aureus with zones of inhibition 12.20 $\mathrm{mm}$ and 9.00 against $L$. plantarum and $L$. brevis respectively. Eschericia coli and $P$. mirabilis had the same zones of inhibition against each of the isolates with values of $8.40 \mathrm{~mm}$ and $8.00 \mathrm{~mm}$ against L. plantarum and $L$. brevis respectively while the least susceptible among them was E. feacalis having $6.50 \mathrm{~mm}$ and $5.70 \mathrm{~mm}$ respectively (Table 2). The selected lactic acid bacteria had been peculiar with the production of antibacterial substances such as acetic acid, bacteriocin, lactic acid and hydrogen peroxide (Fapohunda and Afolayan, 2012; Onwuakor and Ukaegbu-Obu, 2014).

This research work has showed that antimicrobial producing bacteria can be isolated from fermenting cocoa (cocoa juice). The preservative activity of these microorganisms is due to their ability to produce varieties of antimicrobial substances. It was observed that these microorganisms compete and overcame other bacteria in the same community. This will be an innovative approach as alternative to antibiotics in treating infections caused by these pathogens. 


\section{References}

Abdulwahid, B.A., Faiz, I.A., Rasha, S.A. 2013. Extraction and characterization of antibacterial compound from Aspergillus niger. J. Al-Na. Univ. 16(4):167-174.

Adegbehingbe, K.T. and Bello, M. 2014. Antibacterial activities of fermented whey on some selected enteropathogenic bacteria. Int. J. Curr. Microbiol. Appl. Sci. 3:152-161.

Alexopoulous, C.J. and Mims, C.W. 1988. Introductory Mycology. Wiley Eastern Limited, New Delhi. Third Edition, pp. 235-278.

Ardhana, M.M. and Fleet, G.H. 2003. The microbial ecology of cocoa bean fermentations in Indonesia. Int. J. Food Microbiol. 86:87-99.

Atter, A., Obiri-Danso, K. and Amoa-Awua, W. K 2014. Microbiological and chemical processes associated with the production of burukutu a traditional beer in Ghana. Int. Food Res. J. 21(5):1769-1776.

Biehl, B. and Voigt, J. 1996. Biochemistry of cocoa flavour precursors. $12^{\text {th }}$ Edition. International Cocoa Research Conference, Salvador, Brazil. pp. 23.

Cragg, G.M, Kingston, D.G.I and Newman, D.J. 2005. Agents of Natural Products. BocaRaton. FL. pp. 45-55.

De Vuyst, L., Lefeber, T., Papalexandratou, Z. and Camu, N. 2010. The functional role oflactic acid bacteria in cocoa bean fermentation. In: Mozzi, F., Raya R.R. and Vignolo, G.M. (eds,). Biotechnology of Lactic Acid BacteriaNovel Applications. Wiley Blackwell, USA. pp. 56-60.

Fapohunda, S.O. and Afolayan, A. 2012. Fermentation of cocoa beans and antimicrobial potentials of the pod husk phytochemicals. J. Physiol. Pharmacol. 3:158-164.
Galvez, S.L., Loiseau, G., Paredes, J.L., Barel, M. and Guiraud, J.P. 2007. Study on the microflora and biochemistry of cocoa fermentation in the Dominican Republic. Int. J. Food Microbiol. 114:124-130.

González, L., Sandoval, H., Sacristán, N., Castro, J.M., Fresno, J.M. and Tornadijo, M.E. 2007. Identification of lactic acid bacteria isolated from Genestoso cheese throughout ripening and study of their antimicrobial activity. Food Cont. 18:716-722.

Holt, J.G., Kreig, N.R., Sneath, P.H.A., Staley, J.T. and Williams, S.T 1994. Bergey's Manual of Determinative Bacteriology. Williams and Wilkins, Baltimore, USA. pp. 60-75.

Kimball, S. and Jefferson, L. S. 2006. Signaling pathways and molecular mechanisms through which branchedchain amino acids mediate translational control of protein synthesis. J. Nutr. 136 (1):2275-315.

Lima, L.J., Almeida, M.H., Nout, M.J. and Zwietering, M.H. (2011). Theobroma cacao, the food of the gods: quality determinants of commercial cocoa beans, with particular reference to the impact of fermentation. Crit. Rev. Food Sci. Nutr. 51:731-761.

Lopez, A.S. 2007. The contribution of volatile compounds to the flavour of chocolate and their development during processing. PhD Thesis. University of the West Indies/Cacao Research Unit. pp. 35-59.

Motarjemi, Y. 2002. Impact of small-scale fermentation technology on food safety in developing countries. Int. J. Food Microbiol. 75:213-229.

Olivera, I.P., Asher, C.J., Edwards, D.G. and dos Santos R.M.S. 2000. Magnesium sulphate and the development of the common bean cultivated in an Ultisol of Norteast Australia. Sci. Agric. 57:14. 
Onwuakor, C.E and Ukaegbu-Obu, K.M. 2014. Synergestic bio-preservative effects of Vernonia amygdalina leaves and Sacoglottis gabonensis stem bark on palm wine from Elaesis guineensis and Raphia hookeri from Uturu, Nigeria. Ame. J. Microbiol. Res. 3:105109.

Owuamanam, C.I., Ogueke, C.C., Achinewhu, S.C., Barimalaa, I.S. 2011. Quality characteristics of garri as affected by preferment liquor, temperature and duration of fermentation. Ame. J. Food Technol. 6(5):374-384.
Park, J.H., Seok, S-H., Cho, S-A., Baek, MW., Lee, H-Y., Kim, D-J., Hong, U-P. \& Park, J-H. 2005. Antimicrobial effect of lactic acid producing bacteria culture condensate mixture (LCCM) against Salmonella enteritidis. Int. J. Food Microbiol. 101:111-117.

Prescott, L. M., Harley, J. P and Klein, D. A. 2008. Medical microbiology (6th edition) McGraw Hill, New York. pp. 573-736.

Whitkus, R., de la Cruz, M., Mota-Bravo, L. and Gómez-Pompa, A. 1998. Genetic diversity and relationships of cacao (Theobroma cacao) in southern Mexico. Theor. Appl. Gen. 96:621-627.

\section{How to cite this article:}

Kehinde Tope Adegbehingbe, Soji Fakoya, Marcus Oluyemi Bello, Charles Ayodeji Osunla and Samson Olumide Akeredolu. 2019. Antibacterial Activity of Bacteria Isolated from Fermenting Cocoa Water against Some Pathogenic Bacteria. Int.J.Curr.Microbiol.App.Sci. 8(07): 401-408. doi: https://doi.org/10.20546/ijcmas.2019.807.049 